\title{
Translation in/and Hindi Literature
}

\section{Avadhesh Kumar Singh}

\begin{abstract}
The paper is an attempt to study translational practices in different periods in Hindi literature in the following broad areas: (1) Indian linguistic realities and translation in the early period (from early period to 1100) (2) Translation in the Bhakti (1100-1700) and Riti (1700-1800) periods (3) Translation in the Navajagaran Period (1800-1920) (4) Translation in the Swachchandatavad period (1920-1950) (5) Translation in the Adhunik Period (1950-1980) and (6) Translation in the Adhunikottar Period (1980 onwards). The paper focuses on translations into Hindi. It is argued that there are some identifiable trends in each of these periods which help us understand how Hindi internalized alien traditions and defined its mainstream literary culture.
\end{abstract}

\section{Introduction}

Translation in Hindi is bhashantar ('linguistic transference'), parakayapravesh ('transference of spirit from one body to the next, or transmigration'), sweekaran ('making the other as one's own, appropriation'), and even paltukaran ('domestication of the source text in the target linguistic system and culture'). The term is translated as anuvad in Hindi, as in so many other Indian languages. Literally and etymologically, anuvad stands for the 'subsequent' or 'following' discourse (anu=following, $v a d=$ discourse). I prefer the term anuvad to all others, as it means 'subsequent discourse' (target text) based on a vad (discourse, i.e.source text). It presupposes an existing discourse, i.e. vad or source text. The vad and anuvad lead to the third stage, which we

Translation Today Vol. 3 Nos. 1 \& 2, 2006 C CIIL 2006 
can term as samvad (dialogue) with one's own self and other(s) within and without ${ }^{1}$. This dialogue or samvad impacts the self and the other in more ways than one in different historical periods. Attendant political, ideological and economic considerations notwithstanding, samvad becomes an instrument for transformation of the self and the other, as can be discerned in the development of Hindi literature.

The present paper endeavors to study translational practices in different periods in Hindi literature, in the following broad areas: (1) Indian linguistic realities and translation in the early period, (from early period to 1100) (2) translation in the Bhakti (1100-1700) and Riti (1700-1800) periods, (3) translation in the Navjagaran period (4) translation in the Swachhandatavad period (1920-1950), (5) translation in the Aadhunik period (1950-1980), and (6) translation in the Adhunikottar period (1980 onwards). I have limited myself to discussing translation into Hindi and will not discuss translation from Hindi into other languages (something that I propose to explore later). Though true adan-pradan (the process of give and take from one language to another) through translation can be understood only after studying both aspects, the present study, however inadequate it might be, will help reveal the endeavors made in Hindi to equip itself with its own and alien literary traditions in order to transform itself, and in the process, transform other(s) as well.

\section{Translation in the Pre-colonial Period}

Albeit somewhat simplistically, translation in India can be periodized as follows: (1) the pre-colonial, (2) the colonial, and (3) the post-colonial.

The first period can be sub-divided into two: (1) from the beginning (which may be difficult to specify) to 1100 and (2) from 1100 to 1757 . To understand the translational practices in the period 
it is necessary to remember that India has always been multilingual, with Prakrit and Apabhransh as the languages of social transaction and Sanskrit as the language of learned discourse. It was attended by co-existence of diverse styles or riti e.g. Panchali, Avanti, Vidarbhi, Daskshinatya and Gaudi named after various regions. The description of the Kavyapurush ${ }^{2}$ and chakravarti kshetra ${ }^{3}$ in the late tenth century Sanskrit poetician Rajashekhara's Kavyamimamsa bears witness to this. As late as the twelfth century Hemchandra (1089-1173), a Jain monk and a precursor of Gujarati, wrote a grammar of Prakrit but composed his critical treatises, e.g. Kavyanushasana, in Sanskrit. The present Indian multilingualism is a direct descendant of the linguistic pluralism of antiquity. Since Indians have been living with this pluralism for long, they are natural un/conscious translators, who translated without caring for a methodology or theory of translation. Indians existed in multiple languages simultaneously and could shift from one linguistic system to another with ease. In India the sister languages cohabiting their own or collective space were not adversaries. As late as the second quarter of the $19^{\text {th }}$ century, multilingualism flourished in India. For instance, Dayaram in Gujarat wrote in Gujarati and Hindi. Bhartendu Harishchandra (1850-1885) in Hindi called himself in his "Evidence" before the Education Commission a poet of Sanskrit, Hindi and Urdu and composed even in Gujarati. In this sense Indian consciousness was/is essentially translational, though not in the Western sense. The traditions of bhashya (commentary on Hindu sacred texts), tika (sub-commentaries) and anvyaya (determination or explaining meaning by establishing connections or relationships), though written in the same language, were manifestations of this consciousness.

Though anuvad is not an unknown term in Indian tradition, the fact is that there was almost no tradition of translation in ancient India in the modern sense of the term except for bhashya, tika, and vartik (commentary on abstruse sense of text in the tradition of hagiography), which can be considered as translation only in a very 
loose sense. The first two, however, were practised in the same language.

The poets of the Bhakti period (1100-1700) were translators in a different and loose sense, as they strove to translate ancient Indian knowledge and wisdom manifested in different treatises through Sanskrit by appropriating it in various bhashas (native languages). The period from 1100 to 1700 was marked by the lokabhashikaran ${ }^{4}$ of knowledge in Sanskrit. The Bhakti poets namely Nanak, Kabir, Sur, Tulsi, Narsinh, Mira, Gyaneshvar democratized the knowledge in Sanskrit, by transferring it into dialects and lokbhashas (languages of ordinary people). Translation from non-Indian languages into Indian languages and vice versa was less than desired. The translation of the Upanishads into Persian in the seventeenth century by Prince Dara Shikoh and the rendition of the works of Sanskrit poetics into bhashas were notable activities in the period.

The post-Bhakti Riti poets from middle of the seventeenth to the hind quarter of the eighteenth century, operated in more than one language. This period witnessed a continuation of the traditions of tika (commentary), tippani (explanation of difficult words or phrases), bhavanuvad (sense for sense translation) and vartik, the last being marked by translation with explanation. In fact, it is possible to use the term vykhyanuvad (translation with explanation) for it. Along with literary and religious texts, texts belonging to the Vedanta (literally 'end of the Vedas'; it is used for the Upanishads), Vaidyak (medicine) and Jyotish (astrology) schools of thought and narratives from Prakrit and Persian were also translated in this period. Sabal Singh Chauhan (1661-1724), king of Sabalgarh (near Etwah distict in Uttar Pradesh), translated the Mahabharata in the Doha and Chaupai metres in such simple language that it verges on the unpoetic. By comparison, Gokulnath Gopinath's translation of the Mahabharata is more poetic and literary. 
The seventeenth century witnessed translations of Sanskrit works e.g. plays, puranas and narratives into Hindi. Damodardas belonging to Dadu panth (Dadu sect) translated the Markandeya Purana in 1648, and Meghraj Pradhan translated Adhyatma Ramayan. In 1767 Ramahari translated Roopgoswmani's Sanskrit plays as Vidagdh Madhav Natak. Other religious and ethical texts translated in this period included Devichand's Hitopadesh Granth Mahaprabodhini and Banshidhar's Mitra Manohar (1717), both are translations of the old Sanskrit verse narrative Hitopadesh. The Nachiketpuran (the well-known story of Nachiketas in the Kathopanishad ) was frequently translated - as Nachiketopakhyan in 1707 and then in 1831 as Nachiketpuran. Translated as it abundantly was between 1754 and 1769 the Garud Puran (Book of the Dead) was also a favorite among translators. Nazir Anandram's translation of a part of the Padmapuran (Rama's life story) is also worth mentioning here. Surati Mishra translated Vaitalpanchvinshaitika as Vaital Pachchisi, which can be put in the category of chhayanuvad (literally 'shadow translation').

\section{Translation in the colonial period}

The real impetus to translation activities came during the foreign rule from 1757 to 1857 under the East India Company and from 1857 to 1947 under the direct colonial rule, though most of these activities were not free from colonial / political considerations ${ }^{5}$. Thus the next phase of translation in India was a consequence of its colonization in the second half of the eighteenth century. In the first phase the most significant event was the establishment of the Asiatic Society. Among many activities that it supported was also translation of Indian texts into English such as Abhigyanashakuntalam, the Gita, Manusmriti and so on. For the first time translation was pursued in an unprecedented manner in order to (re)discover, know and (re)fashion native knowledge systems which would help to appropriate and control India. Knowing is controlling, and more often than not, translation in the colonial period was the 
means of achieving both goals. It became a means of cultural transformation or conversion of the other that needed to be intellectually domesticated after being politically vanquished.

Excepting the translation of some ancient Indian classics and treatises into Western languages, most of the translations were into Indian languages, and those selected for translation from Western languages (e.g English) to Indian languages were such works as would serve the colonizer's purposes. While English translations of Khayyam's Rubbayat and some of the Indian literary classics were attempted to eroticize the Orient to the West, the translations by William Carey and company of the Bible into 16 Indian language in the 1880 s were motivated more by religious expansionist intentions than by the 'catholicity' of Christianity. Translations from English to Indian languages in subsequent years crushed the Indian creative sensibility, though there is no denying the fact that these translations helped in introducing some new literary trends and movements into Indian literature.

The Asiatic Society was an Orientalist Institute, but not in the Saidean sense, for it did not always act as the handmaid of colonization. The Orientalists, or Indologists to be precise, of the early period from 1757 to 1825 , and their translational operations (associated with the Society at least by the end of the first quarter of the eighteenth century) were inspired by admiration for the Indian's cultural heritage. The translation of the Vedas, Upanishads, Ramayana, Mahabharata, Gita, Manusmruti and Abhigyanashakuntalam among other translations by scholars associated with the Society and others - introduced Indian knowledge systems to Europe. This process of translation from Indian languages to European languages enriched Europe's knowledge about India as a new land with knowledge systems different from its own. The establishment of Chairs of Sanskrit in major universities of Europe, by the first quarter of the $19^{\text {th }}$ century 
was not a mere coincidence but a result of the orientation of Europe towards India through Orientalism.

The nineteenth century witnessed a strengthening of translation activities into Hindi, the Brijbhasha language, to be precise. Lalloolal translated Hitopadesh as Rajneeti in 1802, and the dialogue between the sage Shukdev and King Parikshit as Kalyavankatha and Kimiya-e Shaadat (1817 edn.). Translation of the Bhagavat by Sevaram Mishra and of the Siddhasiddhanta was also attempted in the first half of the $19^{\text {th }}$ century, which was marked by the growth of prose in Brij. Quite a few non-literary texts on religion, poetics, medicine, rituals, astronomy, geography and mathematics were translated into prose mixed with verse. This influenced the language of translation, as may be discerned in Lallolal's translation of Hitopadesh. The vartik and tika traditions continued, and these could be considered as additions to the categories of translation in the loose sense of the term. Also worth noting are the translations of Ved Vyas's Mahabharata and Kalidas's Rutusamhar by Sabal Singh Chauhan (1661-1724) and the tika of the Gitabhashamrata of Ramanuji Bhagvandas (1698), Gita Prashna by Swami Navrang in the eighteenth century, Nazar Anandram's Parmanand -Pravodh Tika (1704), Krishna Chakravarty's Bhagavad-Gita Bhashya, and Hari Vallabh Das's Gitabhashya Tika in verse and prose. Tulsidas's Ramacharitmanas, Bihari's Satsai and Keshav's Rasikpriya, Ramchandrika, Kavipriya and Vairagyashatak also earned the attention of tikakars or commentators. Though tika is not translation in the strict sense of the term, it is translation with latitude - usually in the same linguistic group. These commentaries can be put in the following categories as translation from Sanskrit to the Brij dialect -i.e, commentaries from one dialect to another in the same language group (e.g. from Avadhi to Brij).

Tikanuvad (= translation with commentaries) of different texts in the Riti period were also attempted, for example 
Bhashaupanishad, Bhashapadmapurana, Bhashayogavashishtha, Mallinathcharitavachanika, Sudrashti Tarangini Vachanika, and Hitopadeshvachanika. Bhashaupanishad is a Persian translation of 22 Upanishads, including Taiteriopanishad. The manuscript of this 1719 translation is preserved in the Asiatic Society, Calcutta. The translation of Daulatram Jain's Ramakatha as Bhashapadmapurana or Padmapuran Vachanika from Prakrit to Khariboli, profusely mixed with Rajasthani and Brijbhasha, is worth noting. The interaction between Khariboli and Persian continued in this period, i.e. in the first quarter of the $18^{\text {th }}$ century, as can be seen in Paras Bhag, a translation of Keemia Shaadat by Sevapanthi Addanshah and Kriparam from Persian to Khariboli. Some of the translations from Sanskrit include Gitanuvad, of doubtful authorship but generally ascribed to Birbal (1723 edn.) and Suryasidhanta, a translation of the Sanskrit text of astrology of the same title by Pandit Kamodananda Mishra from Sanskrit in 1782. In general, texts from medicine, astrology, religious and spiritual scriptures, geography, history, philosophy and narratives from Sanskrit and Persian were more commentaries than true translation.

Pandit Yogadhyan Mishra translated Hatimtaee, a famous Kissa which is a narrative dealing with the world of magic and fantasy in 1838; Tarinicharan Mitra translated PurushParikshasangraha dealing with human attributes in 1813; and Dayashankar, the younger brother of Laloolal, translated Daybhag, a text dealing with inheritance of property in 1832. Quite a few Sufi and Islamic religious texts were translated into Dakhini Hindi, which is dominated by Urdu and is closer to Khariboli in word-form and sentence construction. Significant contributions include a translation of Miran Yakoobi's Shamaylul Atakia and Dalaylul Atakia, Mohammad - Valiullah Kadari's translation of Mariftussuluk and also of translation of Saiyad Shah Mohammad Kadiri's Risala-eVajoodiya, Shahmir's Asararuttauhid and Abdul Hamid's Risalae Tasavvuf. Quite a few texts by anonymous authors that were translated in this period are narratives - e.g., Tutinama, Anware 
Suheli, and Kissa-e-Gulo Hurmuz. Sittae Samasiya and Risala Zarre Saken are medical texts translated into Dakhini Hindi. Some of the translations were attempted in consonance with an attitude towards Hindi that was, to a large extent, shaped by the language policy of the rulers. Sadal Mishra's translations of Nachiketopakhyana and Adhyatma Ramayana are its examples. At Sir John Gilchrist instance, Mishra translated the latter work as Ramcharitra in about 320 pages. He wrote:

"The most kind reservoir of all human attributes $\mathrm{Mr}$. Gilchrist Sir resolved to render Sanskrit texts into Bhasha. One day he asked me to render the Adhyatma Ramayana in a language that would have Persian and Arabic words in it. So I started using Khariboli for my purpose" (cited in Ganapatichandra Gupta Vol. II. 737).

Along with original compositions, the Bharatendu period (1850-1885) in the second half of the nineteenth century was marked by sustained translation from Sanskrit and English, the latter activity an offshoot of colonization. Raja Laxman Sigh (1826-96) translated Kalidas's Raghuvansh and his epic poem Meghdoot in simple yet poetic Brijbhasha in Savaiya metre. Bharatendu himself translated a Narad Bhakti Sutra and Shandilya's Bhaktisutra as Tadeeya Sarvaswa in 1874 with greater focus on sense than on linguistic considerations. Babu Totaram (1848-1902) translated Valmiki's Ramayana as Ram Ramayana from Sanskrit to Hindi. In this period, works by the fifth-century poet and dramatist Kalidasa were translated repeatedly from Sanskrit. Thakur Jag Mohan Singh's translations of Kalidasa's Ritusamharam (1876) and Meghdoot (1883) deserve our attention, for he consciously prioritized preservation of sense over literal translation and indirectly tried to adopt translation strategies such as deletion and addition in terms of sense. Lala Sitaram 'Bhoop' (1858-1937) translated Meghdoot (1833), the play Kumarasambhavam (1884), the play Raghuvamsham (1885-92) and Ritusamharam (1893) without 
achieving the effect of Jag Mohan Singh. The major difference between the translations of the two was that the former used tatsama (Sanskrit) phraseology and Kavitta and Savaiya metres, whereas the latter used Doha, Chaupai and Ghanakshari metres. Apart from these, 'Bhoop' translated verses nos. 73 to 85 from the "Adisarga" of Ved Vyas's the Mahabharata as Devyani and also Kapil Muni's Sankhyasutra from Sanskrit to Hindi, although he did not publish it. $\mathrm{He}$ also translated Byron's The Prisoner of Shilon as Shilon $\mathrm{Ka}$ Bandi. Among English works, Oliver Goldsmith's Hamlet and the poem Deserted Village were translated as Ekantvasi Yogi (1886) and Oojad Gram (1889) by Shridhar Pathak into Brijbhasha-mixed Khariboli. Pathak also translated Goldsmith's poem The Traveller as Shranta Pathika. The credit for initiating the process of translating English works into Hindi thus goes to the Bharatendu period.

In 1863 Raja Laxman Singh translated Kalidas's Abhigyana shakuntalam which became popular for two reasons -- the subconscious engagement during the age with Shankuntala's exotic and Dhushyanta's amnesiac story, and the advocacy of purity of language to which Laxman Singh subscribed and practised as well. In this period, apart from Kalidasa, the poet Bhavabhuti was another favourite with the translators of Sanskrit literature. Their works were translated again in this period, showing dissatisfaction with earlier versions. After Raja Laxman Singh's translation of Abhigyana shakuntalam attention was drawn to other works as well. Nandalal Viswanath Dubey also tried to translate the play in 1888, and Lala Sitaram translated Klidasa's play Malvikagnimitra in 1898. Devdutta Tiwari, Nandalal Vishwanath Dubey and Lala Sitaram translated Bhavabhooti's Uttar Ramcharita in 1871, 1886 and 1897 respectively. Sitaram translated Bhavabhooti's play Malatimadhava and Mahavircharita in 1898 and 1897. Lala Shaligram also rendered Maltimadhava in 1881. Shitalaprasad and Ayodhyaprasad Chaudhari translated Krishnamitra's Prabandhachandrodaya in 1879 and 1885 respectively, while Gadadhar Bhatta translated King Shudraka's play Mrchhakatikam in 1880. Important Sanskrit plays translated in this 
period included Harsha's Ratnavali (translated by Devadutta in 1872 and by Balmukunda Singh in 1898) and Bhattnarayana's Venisanhara (translated by Jawalaprasad Singh in 1897). The period, i.e. the second half of the $19^{\text {th }}$ century, is marked by a few tendencies. Most of the translators were creative writers who wanted to enrich their languages with translations. The texts chosen for translations included Sanskrit texts, particularly epics and plays along with English works and even from Bhasha literatures like Bengali and Marathi.

Among other plays, Bharatendu translated the Sanskrit play Chaurpanchashika into Hindi from its Bangla translation in 1868, Ratnavali from Sanskrit in 1868, Pakhand Vikhandan (a translation of the Act III of Krishna Mishra's Pravandhchandrodaya) in 1872, Dhanjayavyaya (a translation of Act III of the Sanskrit play of the same title by Kanchankavi) in 1873, Karpoor Manjari (a translation of Vishakhdutta's play) in 1878. Bharatendu also translated Shakespeare's Merchnt of Venice as Durlabh Bandhu in 1880. The Parsi drama companies staged Shakespeare's plays, and this gave impetus to translation. Arya translated Merchant of Venice as Venice ka Vyapari in 1888, Munshi Imdad Ali rendered Comedy of Errors as Bhramjalak in 1885, while Lala Sitaram rendered it as Bhoolbhulaiya in 1885. Other translations of Shakespeare's plays were As you Like It as Manbhavan by Purohit Gopinath in 1896, Romeo and Juliet as Premlila by Purohit Gopinath in 1877, and Macbeth as Sahsendra Sahas by Mathuraprasad Upadhyaya in 1893. Babu Totram translated Joseph Addison's tragedy Cato as Kratanta in 1879. This trend of translating English plays signalled the importance of English through colonial encounter, and it gave a new direction to Hindi drama, which had availed itself primarily of Sanskrit and folk dramatic traditions. From Bangla, Michael Madhusudan Dutt's plays -- e.g. Padmavati (translated in 1878 by Balkrishna Bhatt), Sharmishtha (in 1880 by Ramcharan Shukla) and Krishnamurari (in 1899 by Ramkrishna Verma) - were translated along with Manmohan Bahu's Sati (in 1880 by Uditnaranyan Lal), 
Rajakishore Dev's Padmavati (in 1889 by Ramkrishna Verma) and Dwarakanath Ganguli's Veer Nari in 1899 by Ramkrishna.

Apart from Bangla plays, novels in Bangla by Bankim Chandra Chatterjee (1833-94), Rameshchandra Dutta (1848-1909) and Tarkanath Ganguli (1845-1907) were also translated. Notable translations include Gadadhar Singh's translation of Rameshchandra Dutt's Bangavijeta (1886) and Bankim's Durgesh nandini (1882), Pratap Narayan Mishra's translation of Bankim Chandra's Raj Singh, Indira, Radharani, and Yugalanguriya, Radhacharan Goswami's translation of Damodar Mukherjee's Mranmayee and Munshi Haritnarayanlal's translation of Swarnkumar's Deep Nirvan.Apart from these, Ramkrishna Verma's translation of Chittorchatki in 1895, Kartikprasad Khatri's Ila (1896), and Jaya Madhumalti and Gopal Das Gahamari's Chaturchanchala (1893), Bhanumati (1894) and Naye Babu (1895) deserve to be noted here, for these translators did not mention the names of the source authors. Gopal Das Gahamari's translations in particular and others in general can be put in the category of translation-cum-adaptation.

Translations from Marathi and Urdu novels included Bharatendu's Poornaprakash Chandraprabha from Marathi and Ramkrishna Verma's Sansardarpan (1885), Amala Vratantamala (1884), Thag Vratantamala (1889) and Police Vratantamata (1890) from Urdu. Some of these translations were discussed and commented upon, with Badrinarayan Chaudhri's 'Premaghan' criticizing Gadadhar Singh's translation of Bangvijeta in detail in Anandakadambini and Balmukund Gupta critiquing the translation of Goldsmith's Hermit as Ekantayoga.

Apart from writing about fifty original works, Mahavir Prasad Dwivedi (1864-1938), after whom the period is named the "Dwivedi Yug [era]" (1893-1918), translated thirty texts. ${ }^{6}$ Rai Devi Prasad 'Poorna' (1868-1915) translated Kalidasa's Meghdoot as Dharadhar-dhawan in 1902. 
In the Dwivedi era, Sanskrit, English and Bangla dramatic texts translated were Savananda Avasthi's translation Naginenda (1956), Mrichohhakatika by Lala Sitaram in 1913, and Uttararamacharita by Kaviratna Satyanarayana. Also, the plays of French dramatist Moliere were translated from their English versions by Lalluprasad Pandey and Gangaprasad Pandey.

Gopaldas Gahamari had introduced detective themes through his detective novels, and he strengthened this with his translation of Arthur Conan Doyle's A Study in Scarlet as Govindram in 1905. The fascination with detective themes and novels continued in the twentieth century. G.W.M. Reynolds' novel, Mysteries of the Court of London was translated as London Rahasya and his Loves of the Hair as Rangmahal by Gangaprasad Gupta in 1904. The fascination with detective stories and the supernatural and miraculous disallowed the use of translation as a mode of introducing new and rich models of novel from non-English traditions such as Russian, French, German, and Spanish, among others. That is how colonization impacts and limits the choices of the subject. However, there were some exceptions as well. For instance, fictional works of literary merit like Daniel Defoe's Robinson Crusoe (under the same title by Janardhan Prasad Jha "Dwij"), and Sir Walter Scott's The Abbott (as Rani Mary in 1916 by Lala Chandralal). Also, there were some non-English novels like Victor Hugo's Les Miserables (by Durga Prasad Khatri as Abhage Ka Bhagya in 1914-15), and Harriet Stowe's Uncle Tom's Cabin (as Tom Kaka Ki Kutiya in 1916 by Mahavir Prasad Poddar). From Bangla, the novels of established novelists like Damodar Mukhopadhyaya, Bankimchandra, Panchakauri De, Rabindranath Tagore and Rameshchandra Dutt were translated respectively by Ishwari Prasad Sharma, Kishorilal Goswami, Gopalram Gahamari and Jonardhan Jha 'Dwij'. All these source texts barring a few exceptions dealt with miracle, mystery or detective incidents in their 
thematic concerns. The absence of translations of serious socially oriented novels speaks of the taste of the then readership in Hindi.

Translation played a role in developing and establishing a critical sense in Hindi. In the Bharatendu period Jagannath Ratnedar had attempted a verse translation of Alexander Pope's Essay on Criticism as Samalochandarsha in 1897. Later Acharya Ram Chandra Shukla translated Joseph Addison's "Essay on Imagination" as Kalpana ke Ananda, and he also translated Edwin Arnold's Light of Asia as Buddha Charita in 1922. Interestingly, this is not in Khari boli Hindi but in Brijbhasha, and Shukla did not take recourse to literal translation. Rather he added to the translation at will. He had previously translated Megasthenese's India as Megasthenesekalina Bharata in 1897, John Henry Newman's Literature as Sahitya in 1904, and Sir T. Madhava Rao's Minor Hints as Rajprabandha Siksha in 1913. Others, such as Mahavir Prasad Dwivedi, made profuse use of English critics without translating or at times even acknowledging them.

Munshi Premchand was a unique case. He used to write his novels in Urdu and then translate them into Hindi - e.g., wrote Bazare Hunsa, Gosh-e-Afimat and Gogane Havti and then translated them as Sevasadan, Premashram and Rangbhoomi. In fact the task was easier, for linguistic code switching between Urdu and Hindi was not difficult for Premchand like northern Indians who operate between the common vocabulary of Hindi and Urdu and their common Gangajamuni culture. Ironically, they were first published in Hindi. In between he translated two of his existing Urdu novels Jalva-e-Isar as Vardan in 1921, and Hamkhurma va Hamsawab as Prem Arthat Do Sakhiyon Ka Vivah. He rewrote the Hindi variance of Prema in Hindi and published it as Pratigya in 1929. He was not happy with the state of the pre-Premchand Hindi novel in comparison with the Urdu and Bengali novel. He saw translation as a means of enriching Hindi literature, but not simply through translation. He was highly critical of the indiscriminate translations 
from Bengali, particularly in the last quarter of the nineteenth century and the early part of the first quarter of the twentieth century. Premchand wanted the treasure of Hindi to be enriched by its own jewels, as well as by the best from other world literatures such as Russian and French. So in his essay "Upanyasa" (Premchand 1962: 33-38) he called upon young people to learn these languages and then translate their good literary works into Hindi.

Acharya Vishweshar translated Abhinavgupta's Abhinav Bharati, Kuntaka's Vakrotijivit, Anandavardhana's Dhwanyaloka, Ramchandra Gunachandra's Natyadarpan and Mammata's Kavyaprakasha. Under the editorship of Dr. Nagendra, Aristotle's Poetics, Longinus's The Sublime and Horacles' Arts Poetica were translated as Arastu Ka Kavyashastra, Kavya Mein Udatta Tattva and Kavyakala respectively.

Quite a few travelogues from Gujarati, Marathi and Bangla by Kanhaiyalal Maneklal Munshi, Kaka Kalelker and Shanker were translated respectively as Badrinath Ki Yatra (1959) Sooryodaya Ka Desh (195), Himalaya Ki yatra (1948) and A Par Bangla O Par Bangla (1982). Other notable translations in the middle decades of the twentieth century include the translation of important short stories of the world as Sansar Ki Sarwashreshtha Kahaniya in 1940 and a translation by Shamsher Bahadur Singh, the Marxist poet, of Aijaz Ahmed's history of Urdu literature as Urdu Sahitya ka Itihasa in 1956.

Memoirs were translated from different languages in the post-Independence period. Ilachandra Joshi was one of the pioneers with his translation of Gorky's Memoirs as Gorky Ke Sansmaran in 1942. Hazari Prasad Dwivedi translated Rabindranath Tagore's memoirs as Mera Bachpan from Bangla. Manuben Gandhi's memoirs were translated by Kurangiben Desai as Ba Meri Man and by Ram Narayan Chaudhary as Ba Aur Babu Ki Sheetal Chhaya Main in 1954. From Panjabi, Amrita Pritam's memoirs were 
translated as Atit Ki Parchaiyan in 1962. Upendra Nath 'Ashq' edited and translated Urdu memoir as Urduke Bhatareen Sansmaran in Hindi in 1962. Mukundilal Shrivastava brought out Nayan Tara Sahgal's Prison and Chocolate from English to Hindi as Mera Bachpan.

The Indian mind's fascination with Shakespeare that had begun in the nineteenth century as a by-product of the colonial literary enterprise continued in the twentieth century. If in the first half of the century Harivanshrai Bachchan translated Shakespeare as part of his academic, creative and personal pursuits, Rangeya Raghav, one of the most prolific translators of Shakespeare, did so more out of his love for Hindi than for Shakespeare. "A language which does not possess translations of Shakespeare, cannot be counted among the more developed languages" (cited in Trivedi 1993, 33). Further, retranslation of Shakespeare's plays speaks of his dissatisfaction with the preceding translations of Shakespeare, for Shakespeare was already there in Hindi but not in the kind of translations that Rangeya Raghava wanted.

Another notable feature of translation into Hindi in the second half of the twentieth century was the participation in the translational enterprise of noted creative and critical writers, both established and emerging, against the backdrop of a realization of the significance of translation as the means of enriching their literature and their own creativity. Vishnu Khare's translation of The Wasteland and Mohan Rakesh's translation of The Portait of a Lady speak of their choice of Anglo-American-centric texts more out of their fascination for them and less out of their canonical status in the Hindi academic world. Incidentally, both of these translators were not directly concerned with the academic world. Others moved away from the Anglo-American space to a large extent, such as the translation of Albert Camus' The Stranger by Rajendra Yadav and Bertolt Brecht's The Caucasian Chalk Circle by Kamleshwar. Kedarnath Singh translated Paul Eluard's poems and discovered his 
own poetic talent in the process, and became one of the significant Hindi poets of the last quarter of the twentieth century.

In the 1960s and 1970s, translation into Hindi moved further away from England and America to central and eastern European countries such as Czechoslovakia, Yugoslavia, Hungary, Poland and Russia. Through the choice of source texts this constituted indirect resistance to American hegemony. The case of Nirmal Verma stands out. The translations of Czech creative literature (particularly of Milan Kundera) by this eminent Hindi novelist and essayist introduced Czech creativity to the Hindi readership even before it reached English, and Verma made use of Czech locales in his maiden novel. Raghuvir Sahay, a distinguished poet, translated Hungarian poets, the Polish novelist Jerzi Andrezejewaski, and the Yugoslavic/Bosnian poet Ivo Andric. Sahay's translation of Andric's epic novel Na Drini Chupriya as Drina Nadi Ka Pul (1986) is significant because of his choice of the text for translation. He selected it after becoming fascinated with Andric's delineation of characters and their conduct, the struggle for oppositional values within European history, and also in an attempt to make the sympathetic Indian reader conscious of the present state of India and its future. Commenting on Andric's appeal to him, he said,

"In his work, while people accept the new, they do not barter away the old for it. This is the true meaning of knowing one's tradition; and this is also the Indian philosophy of history."

In Sahay, translation thus becomes an instrument of knowing and reinstating one's own cultural and philosophical traditions through similar literary works and traditions from hitherto unknown lands. Writings from Latin America, Africa and the Caribbean came to be translated into Hindi. Virendra Kumar Barnwal translated Wole Soyinka's poems as Wole Soyankaki Kavitayen in 1991 out of his love or affinity for the poet and his 
work, not out of any translational ideals. The shift of the centre of fictional creativity to the non-American and non-European world such as South America, Africa and Asia, discernible as it is, in awards like the Nobel Prize and the Commonwealth and Booker Prizes to non-European and non-American writers introduced the works of these writers to Hindi literature through translation. In addition to Teen Saal (Chekhov) Agneya Versha (Constantine Faydin), Surkh aur Syah (Stendhal), Dheere Bahe Don (Mikhail Sholokhov), Pahala Adami, Azanabi, Plague, Patan, Sukhi Mratyu (all by Albert Camus), Kisan (Balzac), Gabriel Garcia Marquez's One Hundred Years of Solitude as Ekant Ke Sau Varsha were translated. Indian English writing such as Vikran Seth's A Suitable Boy and An Equal Music were translated as Ek Achchha sa Ladka and Ek sa Sangeet respectively, Salman Rushdie's Haroun and the Sea of Stories as Haroon aur Kahaniyon ka Samunder, Khushwant Singh's Train to Pakistan as Pakistan Mail, and Shobha De's Starry Nights as Sitaron ki Raten.

This period was remarkable for another translational tendency viz. of translating Urdu poetry into Hindi, though it meant mere transcription of Urdu poets like Ghalib in Devanagari script with meanings of difficult words given in Hindi.

In the post-colonial period various literary and cultural institutions (Central and State Sahitya Akademis) and publication houses such as Katha, Macmillan and the National Book Trust encouraged translation to facilitate interaction among various linguistic identities. The main tendencies included a critique of colonial translations and their motivations and ideologies, translations of works from post-colonial societies into Indian languages and also from Eurasian countries, a shift from the word/sentence/paragraph or vision to culture as the unit of translation, and the use of English as an intermediary language. Towards its close the twentieth century witnessed 'horizontal' translations (Adan Pradan) among Indian languages more than ever. 
The declining decades of the twentieth century witnessed a new upsurge in translation that was unbridled by colonial complexes and calculations but not always politically innocent. The translation scenario in Hindi might not compare favourably with English, but it is quite healthy because of the large Hindi readership and greater acceptance of Hindi among other sister languages. Among several reasons that may be adduced for this phenomenon are the emergence of a new crop of good writers in Indian languages who want to have an access to Hindi readership through translations. Some concerted efforts by the Sahitya Akademi (the National Academy of Letters) were made in collaboration with other agencies in this direction. The entry of some new publishing houses such as Bharatiya Gyanpith and Sahitya Akademi along with Hindi Akademis in many states have given a new impetus to translation in Hindi by getting most of the award winning works translated into Hindi. Academic Hindi publishers like Vani, Rajkamal, Radhakrishna, showed greater inclination for publishing important works from non-Indian languages like English, French, German, Russian, and also Latin American and African languages. Another notable feature was the emergence of dalit and feminist discourse. So, literary works dealing with them were translated. Since the dalit discourse flourished more in Marathi than in any other language, the works of Daya Pawar and Sharan Kumar Limbale were translated and published in Hindi by Vani, Rajkamal and Radhakrishna in particular.

I will conclude with the remark that translational practices prevalent at that time in India, especially in Hindi, have to take note of the linguistic clusters in the country, as there used to be five Prakrit or natural languages of the people viz. Panchali, Avanti, Vaidarbhi, Gaudi, and Dakshinatya. In ancient India there were eight linguistic clusters:

1. TMKT: Tamil, Malayalam, Kannada, Telugu

2. MKKT: Marathi, Konkani, Kannada, Telugu

3. HGM: Hindi, Gujarati, Marathi 
4. HPGMBO: Hindi, Punjabi, Gujarat, Marathi, Magadhi, Oriya, Bengali

5. ABO: Assamese, Bengali, Oriya

6. AGK \& NE: Assamese \& North-eastern dialects/languages

7. PDHT: Panjabi, Dogri, Hindi, Tibetan/Ladakhi

8. HOTM: Hindi, Oriya, Telugu, Marathi

They exist on the geographical map of India. The need is of greater translational interactions among them. The interaction among Indian languages would lend impetus to translation in Hindi because Hindi touches major linguistic clusters barring the southern linguistic cluster. This is what I would term as 'Home and Abroad' approach to translational activities followed by 'Home and Abroad' phenomenon which has plagued translational pursuits in India. First there should be translation amongst sister languages of India and then between Indian and non-Indian languages. Hindi, by virtue of its leadership and demographic space covering more than forty crores of people within India, would be the greatest beneficiary of this 'Home \& Home' and then 'abroad' proposal of translational practice. ${ }^{7}$

\section{NOTES}

1. The terms vad, anuvad and samvad are a variation of the title of the book Vad, Vivad aur Samvad by the noted Hindi critic, Namvar Singh. The title of the book is a creative translation of Hegelian dialectical terms: thesis, anti-thesis and synthesis. In both the cases the beginning and the end are the same though, in the second and central stage anti-thesis and translation or subsequent discourse occupy the central place in their respective paradigm. I consider samvad and synthesis to be reciprocal processes because synthesis is a consequence of dialogue. 
2. Kavyapurush (=verbal/literary discourse incarnate) is a mythical account of the origin of literature and its forms given in Chapter III of Kavyamimamsa. Goddess Saraswati, mother of Kavyapurush, appreciates him, as he is the first creator of verse:

"Words and meaning form your body, Sanskrit your mouth, Prakrit dialects your arms, Apabhrmsha your legs, Pisachi your feet and Mishra languages your bosom. You are complete, happy, sweet and largehearted. Your speech is elevated. Rasa is the soul."

3. In Chapter III of Kavyamimamsa, Chakravarti kshetra is described to be from the Southern Sea to the Himalayas covering an area of one thousand yojanas (about four thousand miles). The poets of the country can describe the apparel, manners, customs and speech of these geographical areas.

4. I prefer this term to 'vernacularisation' because it has a politically dismissive connotation in it. Lokbhashaikaran includes in it democratization of knowledge, first composed in Sanskrit through the process of its transference into lokbhashas ('native' laguages is politically incorrect). For an elaborate note on this, see AK Singh (my article) "Neither Amnesia nor Aphasia: Knowledge, Continuity and Change in Indian Poetical traditions" in Indian Knowledge Systems, Vol. 2, 372-3.

5. For an elaborate discussion, see (my article) "Renaissance Self(Re) Fashioning" in South Asian Review, Pennsylvania University.

6. Panditraj Jagannath's Bhavini Vilasa from Sanskrit in 1891 and Yamunastrota as Amrutalahiri in 1896, Bacon's famous essays as Bacon Vichar in 1901, Herbert Spenser's essay "Education" as "Shiksha" in 1906, John Stuart Mill's essay On Liberty as Swadheenata 1907, the Mahabharata as Hindi Mahabharata in 1908, Kalidas's Raghuvansha, Kumar Sambhava and Meghdoot in 1912, 1915 and 1917 respectively, Bhattnarayana's 
Venisnghara 1913, Bharavi's Kiratarjuniyam in 1917, and Akhyayika Saptaka, the translation of seven selected narratives, in 1927.

7. For an elaborate discussion of this point, see (my articles) "Decolonising Engish Studies in India" in Decolonisation: A Search for Alternatives eds. Adesh Pal et al. New Delhi: Creative books, 2001, and "A Case for Comparative Literay Studies" in English Studies: Indian Perspective. eds. Makarand Paranjape et al. New Delhi: Mantra Books, 2005.

\section{REFERENCES}

Gupta, Ganapatichandra (ed) 1995 Hindi Bhasha and Sahitya Vishwakosha Vol. II. Delhi: Atlantic Publishers.

Harishchandra, Bhartendu 2000 Bhartendu Samagra Varanasi: Pracharak Granthavali.

Nagendra 2001 Hindi Sahitya Itihasa Noida: Mayur Paperbacks.

Premchand, Munshi 1962 "Upanyasa” Vividh Prasang Vol. III (ed) Amrit Rai Allahabad: Lokbharati.

Sahay, Raghuvir 1986 "Prastavana” Drina Nadi ka Pul (translation of Ivo Andric's novel $\mathrm{Na}$ Drini Chupriva) New Delhi: Sahitya Adkademi.

Shukla, Acharay Ramchandra 2003 Hindi Sahitya Ka Itihasa New Delhi: Prakashan Sansthan.

Singh, Avadhesh Kumar (ed) 1996 Translation: Its Theory and Practice New Delhi: Creative Books.

Singh, Bacchchana 2000 Hindi Sahitya ka Doosara Itihasa Delhi: Radhakrishna Prakashana.

Trivedi, Harish 1993 Colonial Transactions: English Literature and India Culcutta: Papyrus. 
